\title{
Elevated serum placental isoferritin in newly diagnosed Type 1 (insulin-dependent) diabetes mellitus. A possible marker for identification of high risk subjects
}

\author{
S. Assa ${ }^{1}$ and C. Moroz ${ }^{2}$ \\ ${ }^{1}$ Institute of Pediatric and Adolescent Endocrinology and \\ ${ }^{2}$ Rogoff Medical Research Institute, Beilinson Medical Center, Petah-Tikva, Sackler School of Medicine Tel-Aviv University, Israel
}

\begin{abstract}
Summary. Placental isoferritin is produced by activated $T$ lymphocytes and may, therefore, be considered as a manifestation of T cell involvement. Placental isoferritin is measured using $\mathrm{CM}-\mathrm{H}-9$ monoclonal antibody which binds exclusively to placental isoferritin. Placental isoferritin has been determined in the serum of 80 patients with Type I (insulin-dependent) diabetes mellitus, 100 healthy first degree relatives and 81 healthy children. Serum levels which were measured in Type 1 diabetic patients, $(24,0-140 \mathrm{U} / \mathrm{ml}$; median and range) were significantly higher than those of family members $(0,0-73$; median and range; $p<0.0001)$ and normal control subjects $(0,0-48$; median and range; $p<0.0001)$. Using $0-$ $10 \mathrm{U} / \mathrm{ml}$ as the upper limit of normal, it was found that 31 of $50(62 \%)$ of Type 1 diabetic patients, 25 of $100(25 \%)$ family members and 7 of $81(8.6 \%)$ healthy control subjects had abnormal placental isoferritin levels. Islet cell antibodies were
\end{abstract}

positive in 31 of 44 tested diabetic patients and, in 8 of 71 tested family members, and among them $54.8 \%$ and $50 \%$ respectively also had elevated placental isoferritin levels. However, no statistically significant correlation was found between islet cell antibodies and placental isoferritin levels. Treatment of Type 1 diabetic patients with insulin was accompanied by a significant decrease $(p<0.002)$ of serum placental isoferritin within $2-4$ weeks of treatment. It is noteworthy that placental isoferritin was below detection in 34 of 35 Type 2 (non-insulin-dependent) diabetic patients. Our findings suggest that placental isoferritin may be a marker of $T$ cell involvement in autoimmune diabetes and that it could be used to identify high risk healthy first degree relatives.

Key words: Placental isoferritin, Type 1 (insulin-dependent) diabetes, monoclonal antibodies, islet cell antibodies.
Genetic predisposition, susceptibility to environmental stimuli and autoimmune mechanisms interact to cause Type 1 (insulin-dependent) diabetes mellitus. The appearance of Type 1 diabetes is accompanied by multiple circulating autoantibodies: islet cell antibodies (ICA), islet cell surface antibodies (ICSA), insulin autoantibodies (IAA) and anti-64 kilodalton (kd) antibodies. Some of these autoantibodies are observed in $50-90 \%$ of newly diagnosed Type 1 diabetes patients and in $30-50 \%$ of their first degree relatives [1-5]. There is accumulating evidence which supports the importance of T-cell mediated autoimmunity in the initiating events of the islet Beta-cell destruction [6-8].

We have recently reported that one of the changes which occur in human $T$ lymphocytes during activation with conconavalin $\mathrm{A}$ is the appearance of a peptide of $43 \mathrm{kd}$ coded by a unique mRNA species [9]. This peptide cross-reacted with a CM-H-9 monoclonal antibody which is specific for placental isoferritin (PLF) [10]. PLF is an immunosuppressive protein [11], acting as a down regulator of the immune response of mothers against their embryos [12]. High levels of PLF were measured with CM-H-9 monoclonal antibody in women during pregnancy whereas it is below detection in the majority of healthy adult blood donors [13]. Elevated levels of PLF were also measured in serum, from patients with pathological conditions such as lymphoproliferative disorders, and breast cancer $[14,15]$, in patients with autoimmune diseases such as coeliac disease [16] and multiple sclerosis (unpublished observations) in which $\mathrm{T}$ cell involvement has been reported in the aetiology of the disease, and in patients with HIV infection [17].

The above findings prompted us to investigate whether Type 1 diabetes is also associated with high serum levels of PLF.

\section{Subjects and methods}

\section{Subjects}

Included in the study were three groups of Type 1 diabetic patients, all treated in the Institute of Pediatric and Adolescent Endocrinology, Beilinson Hospital. The first group consisted of 50 patients (29 male, 21 female) age $2.5-29$ years ( $12.5 \pm 4.8$ years, mean $\pm S D$ ) with Type 1 diabetes, new-onset or insulin-treated for 1-7 days. The second group consisted of 23 patients ( 13 male, 10 female) age $3.5-20$ years $(13.3 \pm 4.1$ years) under insulin treatment for a period of $2-28$ weeks and the third group, 7 patients treated with insulin for a period of one year.

In addition, 100 healthy first-degree relatives were included: 27 mothers, 27 fathers, 46 siblings ( 23 sisters, 23 brothers), as well as 81 


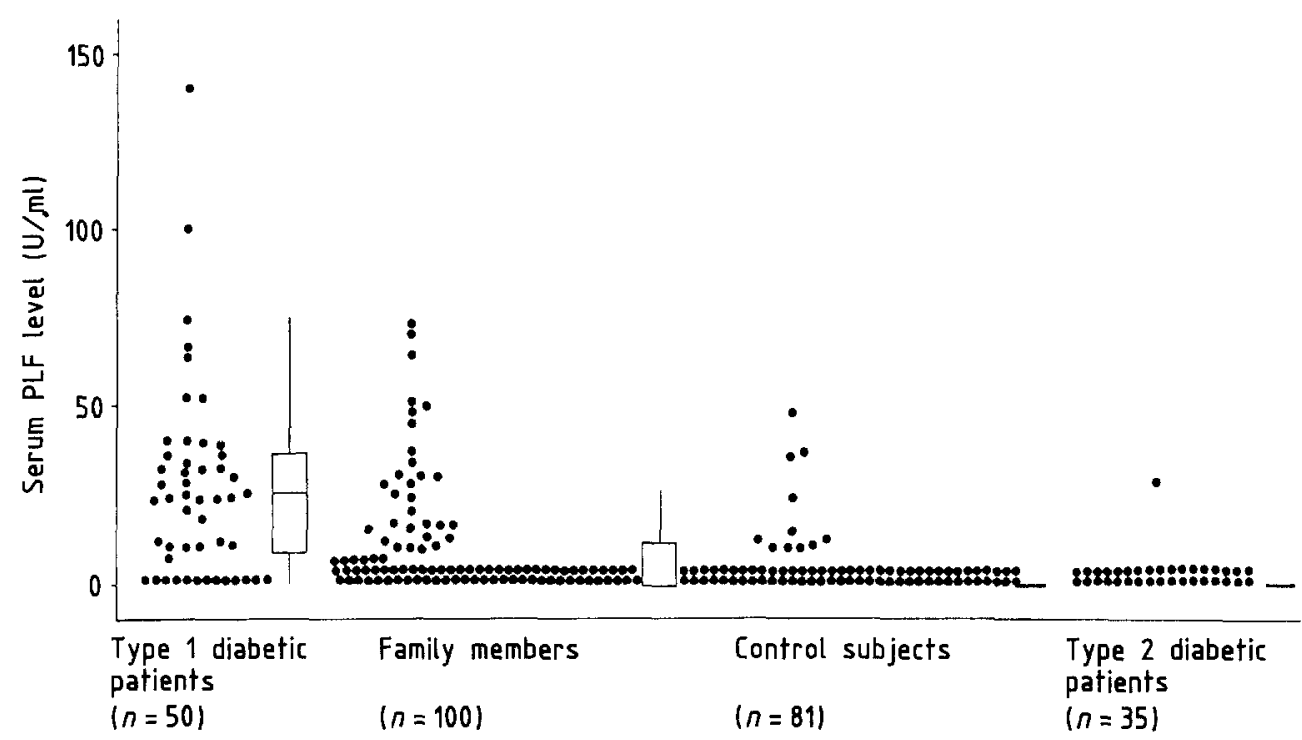

Fig.1. Scattergram of serum placental isoferritin (PLF) levels in Type 1 (insulin-dependent) diabetic patients, in their healthy family members, in healthy control subjects and in Type 2 (non-insulin-dependent) diabetic patients, with correspondent box and whisker plots, initiating median, lower $\left(25^{\text {th }}\right)$ and upper $\left(75^{\text {th }}\right)$ centile and minimalmaximal values (whiskers) healthy control subjects age $3.5-19(13.0 \pm 3.9$ years $)$ having no family history of Type 1 diabetes or Type 2 (non-insulin-dependent) diabetes. For comparison, 35 Type 2 diabetic patients were also included.

Blood samples from Type 1 diabetic patients are routinely obtained in our Institue for standard diagnostic laboratory tests. Blood samples from the family members were collected for the screening of high risk relatives of the diabetic proband. The healthy subjects had been referred to the Institute for developmental evaluation and blood was drawn for routine examinations. Informed consent was obtained from all patients, control subjects and from their parents. The study was approved by the Israel Ethical Comittee and the Ministry of Health.

\section{Laboratory methods}

Assay for ICA. ICA were determined by an indirect immunofluoresence technique on unfixed cryostat sections of blood group 0 pancreas [1].

Assay for PLF. Serum PLF levels were determined by a previously described ELISA method [14]. The assay utilised two monoclonal antibodies (CM-G-8 and CM-H-9). CM-G- 8 monoclonal antibody binds to all isoferritins whereas $\mathrm{CM}-\mathrm{H}-9$ monoclonal antibody binds to PLF only [10]. The amount of PLF that bound $250 \mathrm{pg}$ of alkaline-phosphatase conjugated CM-H-9 monoclonal antibody was arbitrarily considered to be $10 / \mathrm{U}$ of PLF and the results were expressed as $\mathrm{U} / \mathrm{ml}$.

\section{Statistical analysis}

Values are given as median and range. Because PLF values showed skewed distribution the Mann-Whitney U-test (two-tailed probability) was used. Correlation between the age and PLF values was calculated by regression analysis.

\section{Results}

A scattergram of the serum levels of PLF in the Type 1 diabetic patients, their first degree-healthy family members, normal control subjects and the Type 2 diabetic patients is presented in Figure 1. A wide range of serum PLF levels was observed in the diabetic patients as well as in some of their healthy family members. In contrast, PLF was undetected or at very low levels in most subjects of the control group and in the Type 2 diabetic patients. ICA were found in 31 of 44 diabetic patients tested of whom 17 (54.8\%) had elevated PLF levels, above $10 \mathrm{U} / \mathrm{ml}$ (not shown). ICA were positive in 8 of 71 tested healthy family members of Type 1 diabetic patients of whom $4(50 \%)$ also had elevated serum PLF levels (not shown). All the control subjects were ICA negative. The median and range serum PLF level (24, 0-140 U/ml) in the Type 1 diabetic patients was significantly higher $(p<0.0001)$ than in their family members $(0,0-73 \mathrm{U} / \mathrm{ml})$ and in that of normal control subjects $(0,0-29 \mathrm{U} / \mathrm{ml} ; p<0.0001)$ (Table 1$)$.

Designating 0-10 U/ml as a normal level of PLF, it was found that $62 \%$ of Type 1 diabetic patients had an elevated PLF level compared to $25 \%$ of their family members, $8.6 \%$ of the control subjects and $2.9 \%$ of Type 2 (non-insulin-dependent) diabetic patients (Table 1).

Table 1. Serum PLF levels in patients with Type 1 (insulin-dependent) diabetes mellitus, their families and in Type 2 (non-insulin-dependent) diabetic patients

\begin{tabular}{|c|c|c|c|c|c|}
\hline \multirow[t]{2}{*}{$\begin{array}{l}\text { Subjects } \\
\text { tested }\end{array}$} & \multicolumn{2}{|c|}{$\begin{array}{l}\text { Serum PLF level } \\
\mathrm{U} / \mathrm{ml}\end{array}$} & \multirow[t]{2}{*}{$\begin{array}{l}\text { Patients with } \\
\text { elevated PLF }\end{array}$} & \multirow[t]{2}{*}{$\%$} & \multirow[t]{2}{*}{$P^{\mathrm{C}}$} \\
\hline & Median & Range & & & \\
\hline Type 1 diabetic patients $\mathrm{s}^{\mathrm{a}}$ & 24 & $0-140$ & $31 / 50$ & 62.0 & \\
\hline Family members & 0 & $0-73$ & $25 / 100$ & 25.0 & $<0.0001$ \\
\hline Control subjects ${ }^{d}$ & 0 & $0-48$ & $7 / 81$ & 8.6 & $<0.0001$ \\
\hline Type 2 diabetic patients & 0 & $0-29$ & $1 / 35$ & 2.9 & $<0.0001$ \\
\hline
\end{tabular}

a Patients at diagnosis before treatment or insulin treated for 1-7 days; ${ }^{b}$ Elevated level $>10 \mathrm{U} / \mathrm{ml} ;{ }^{c}$ Significantly different than patients with Type 1 diabetes by Mann-Whitney U-test (two-tailed probability); ${ }^{\mathrm{d}}$ Children referred to paediatric endocrinology clinic with no evidence of disease. PLF = Placental isoferritin

Table 2. The incidence of elevated PLF levels in family members of Type 1 (insulin-dependent) diabetic patients

\begin{tabular}{lrrr}
\hline Subjects tested & \multicolumn{3}{c}{ Members with elavated PLF } \\
\cline { 2 - 4 } & $n$ & $n$ & $\%$ \\
\hline All family members & 100 & 25 & 25.0 \\
Fathers & 27 & 5 & 18.5 \\
Mothers & 27 & 6 & 22.0 \\
Brothers & 23 & 5 & 22.0 \\
Sisters & 23 & 9 & 39.0 \\
\hline
\end{tabular}

a Elevated level $>10 \mathrm{U} / \mathrm{ml}, \mathrm{PLF}=$ Placental isoferritin 


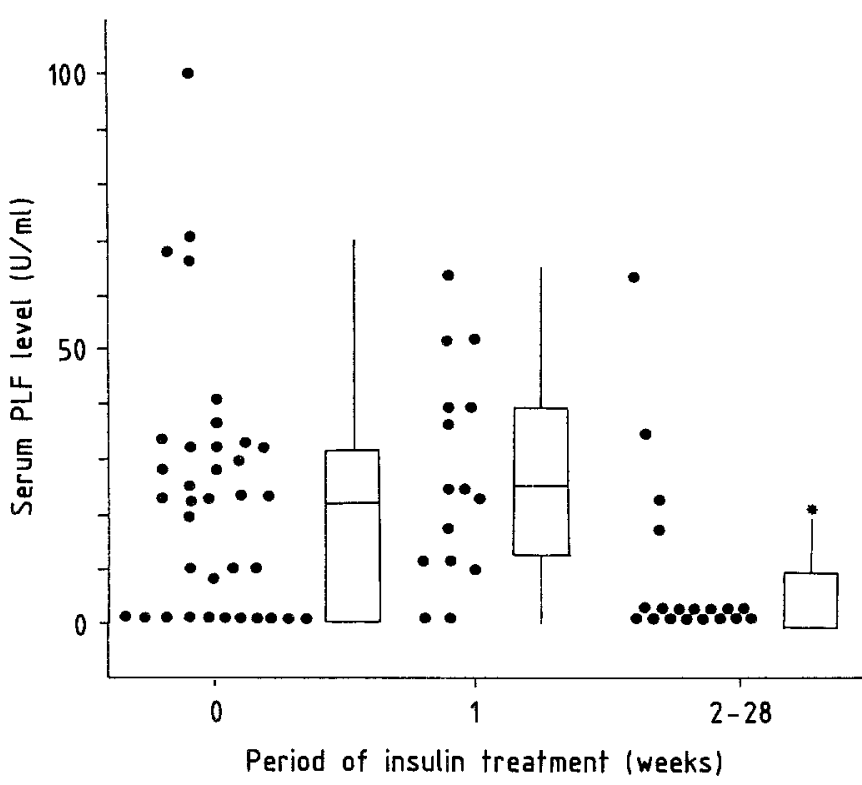

Fig. 2. Comparison of serum placental isoferritin (PLF) levels in Type 1 (insulin-dependent) diabetic patients at diagnosis and under insulin treatment, with correspondent box and whisker plots, initiating median, lower $\left(25^{\text {th }}\right)$ and upper $\left(75^{\text {th }}\right)$ centile and minimal-maximal values (whiskers). * significantly lower than untreated patients $(p=0.002)$

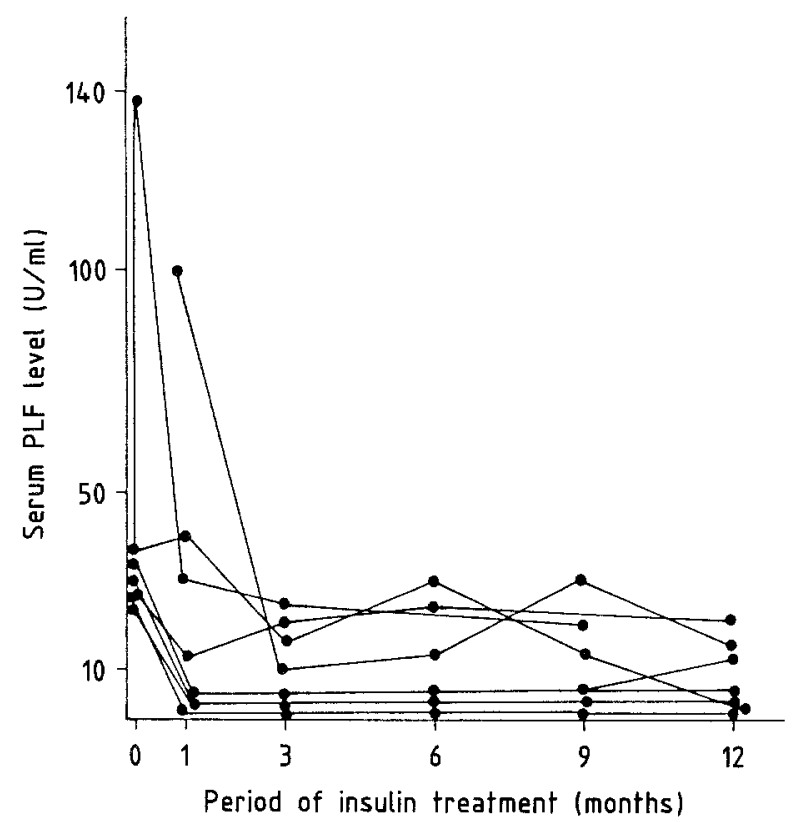

Fig. 3. Serum placental isoferritin (PLF) levels in Type 1 (insulin-dependent) diabetic patients during one year of insulin treatment

No statistically significant correlation was found between the age and PLF values in the patients with Type 1 diabetes $(r=-0.189)$ or in the control subjects $(r=-0.125)$.

Among the family members, the highest percentage of elevated PLF results were found in the siblings of the Type 1 diabetic patients (30.4\%). In mothers and fathers, positive results were found in $22.2 \%$ and $18.5 \%$, respectively of those tested parents (Table 2). It was further observed that in relatives of Type 1 diabetic patients with positive PLF results, $37.8 \%$ were PLF positive as com- pared to $0 \%$ in relatives of PLF negative probands (Table 3). Further, the level of serum PLF was measured in Type 1 diabetic patients under insulin treatment. As seen in Figure 2, decreased mean PLF levels were observed in patients under insulin treatment. The lowest level was measured in the group treated with insulin for $2-$ 28 weeks. It was significantly lower $(p<0.002)$ than in Type 1 diabetic patients as diagnosis and was similar to the level of the control group. The early decrease of serum PLF levels in Type 1 diabetic patients following insulin treatment, was further confirmed in seven patients tested repeatedly during one year. It can be seen in Figure 3, that a sharp decline was observed in 6 of 7 patients tested, after one month of insulin treatment. This effect was stable for one year of follow-up (Fig. 4).

\section{Discussion}

The results of the current study revealed that PLF was significantly elevated in patients with Type 1 diabetes at diagnosis and in some of their family members, but not in Type 2 diabetes.

To date, the tests for diagnosis of autoimmune Type 1 diabetes and family members at risk, included determination of humoral autoantibodies i.e. ICA, ICSA, IAA and anti-64KD antibodies. PLF, on the other hand, is a protein produced by activated T lymphocytes [9]. High levels of this protein were found also in patients with coeliac disease [16] and in multiple sclerosis (unpublished observation) which manifest other autoimmune diseases with $\mathrm{T}$ cell involvement. In coeliac patients, it was found that PLF was produced by the lymphocytes infiltrating the gut, the target organ in this disease (unpublished observations). The origin of serum PLF in Type 1 diabetes is as yet unknown. However, it may be suggested that PLF originates from $\mathrm{T}$ lymphocytes which infiltrate the diabetic pancreas. Direct involvement of $\mathrm{T}$ cell interference in Type 1 diabetes was first observed by Gepts [18] and Botazzo et al. [19]. Both groups described "insulitis" characterised by lymphocyte infiltration in the pancreas of a diabetic child who died soon after the onset of the disease. The infiltrate constituted mainly of $\mathrm{T}$ cytotoxic/suppressor cells, $\mathrm{T}$ helper, and B cells. Therefore, the high PLF level may be considered a manifestation of $\mathrm{T}$ cell involvement in the disease.

$\mathrm{T}$ lymphocytes from peripheral blood of Type 1 diabetes patients can suppress secretion of insulin from cultures of islet beta-cells [20]. Recently, de Berardinis et

Table 3. Incidence of positive serum PLF levels in Type 1 (insulindependent) diabetic patients and their first degree relatives

\begin{tabular}{llll}
\hline & \multicolumn{2}{l}{ Proband } & \\
\cline { 2 - 4 } & PLF & PLF & \\
& $\begin{array}{l}(+) \\
\mathrm{n}=13\end{array}$ & $\begin{array}{l}\text { Total } \\
n=7\end{array}$ & $n=20$ \\
& & & \\
\hline Relative (+) & $14(37.8 \%)$ & $0(0 \%)$ & 14 \\
Relative (-) & $23(62.2 \%)$ & $15(100 \%)$ & 38 \\
Total & 50 & 22 & 72 \\
\hline
\end{tabular}

PLF = placental isoferritin; $(-)$ Placental isoferritin $0-10 \mathrm{U} / \mathrm{ml}$; $(+)$ placental isoferritin above $10 \mathrm{U} / \mathrm{ml}$ 
al. [21] showed that $\mathrm{CD}_{4}$ positive activated $\mathrm{T}$ cell clones isolated from a Type 1 diabetes patient of acute onset were specifically cytotoxic to islet Beta-cells.

In addition, Pak et al. [22] recently demonstrated the presence of human cytomegalovirus specific viral genome in the lymphocytes of 15 newly diagnosed Type 1 diabetes patients, suggesting an association between persistent cytomegalovirus infection and Type 1 diabetes.

The current study shows for the first time a new marker (PLF) of T cell activation of high incidence in Type 1 diabetic patients and their family members. Among the family members the incidence of positive PLF was highest in healthy siblings. This finding may suggest that these subjects are at the highest risk for developing Type 1 diabetes and may need further evaluation and follow-up.

Of great interest is the observation that PLF was decreased in Type 1 diabetic patients after short periods (228 weeks) of insulin treatment and in those followed up to one year. This may be interpreted as an insulin suppressive effect on activated $\mathrm{T}$ lymphocytes producing this protein.

The mechanism of the insulin effect on secretion of PLF is unknown. PLF has been previously shown to exert an immunosuppressive effect $[11,12]$ and may, thus, participate in alteration of the immune function of Type 1 diabetic patients.

It was previously found that insulin treatment may partially restore the altered function of the immune system in BB rats [23], in experimental models and in Type 1 diabetes of recent onset [24], thereby slowing the autoimmune process. Interestingly, a new study demonstrated that intensive insulin therapy during the first two weeks from the onset of Type 1 diabetes, resulted in an improved islet Beta-cell function during the subsequent year [25]. Inhibition of PLF secretion by insulin may be responsible for part of this restorative effect.

The results of this study may further support the recently projected trial for insulin pre-treatment of family members at high risk. This treatment may result in a decreased PLF level, restoration of immunological functions and a reduced risk of developing diabetes.

Acknowledgements. The authors thank Prof. Z.Laron for encouragement and critical review of this manuscript, Dr. P. Vardi, for valuable criticism, Dr. Z. Dickerman for his help in statistical evaluation of the data, Dr. M. Rapoport for supplying the sera from patients with Type 2 diabetes, Mrs. B. Zingerman for excellent technical assistance and Mrs. A. Yaari for managing the computer data.

\section{References}

1. Bottazzo GF, Florin-Christensen A, Doniach D (1974) Islet cell antibodies in diabetes mellitus with autoimmune polyendocrine deficiencies. Lancet II: 1259-1282

2. Lernmark $\AA$, Freedman ZR, Hofman C, Rubinstien AM, Steiner DF, Jackson RL, Winter RJ, Traisman HS (1978) Islet-cell surface antibodies in juvenile diabetes mellitus. $N$ Engl $\mathbf{J}$ Med 299: $375-380$

3. Palmer JP, Asplin CM, Clemons P, Lyen K, Tatpati O, Raghu PK, Paquette TL (1983) Insulin autoantibodies in insulin dependent diabetics before insulin treatment. Science 222: 1337-1339

4. Baekkeskov S, Nielsen JH, Marner B, Bilde T, Ludvigsson J, Lernmark $\AA$ (1982) Autoantibodies in newly diagnosed diabetic children immunoprecipitate human human pancreatic islet cell proteins. Nature 298: 167-169

5. Vardi R, Dib SA, Tuttleman M, Connelly JE, Grinbergs M, Radizabeh A, Riley WJ, MacLaren NK, Eisenbarth GS, Soeldner JS
(1987) Competitive insulin autoantibody assay. Prospective evaluation of subjects at high risk for development of type I diabetes mellitus. Diabetes 36: 1286-1291

6. Mandrup-Poulsen T (1988) On the pathogenesis of insulin-dependent diabetes mellitus. Dan Med Bull 35: 438-469

7. Rossini AA, Mordes JP, Like AA (1985) Immunology of insulindependent diabetes mellitus. Ann Rev Immunol 3: 289-320

8. Bach J-F (1988) Mechanisms of autoimmunity in insulin-dependent diabetes mellitus. Clin Exp Immunol 72:1-8

9. Moroz C, Shterman N, Kupfer B, Ginzburg C (1989) T cell mitogenesis stimulates the appearance of a new mRNA species coding for a $43 \mathrm{KD}$ peptide reactive with CM-H-9 monoclonal antibody specific for placental isoferritin. Proc Natl Acad Sci 86: $3282-3285$

10. Moroz C, Kupfer B, Twig Sh, Parhami-Seren B (1985) The "common" and "private" antigenic determinants of placental ferritin defined serologically by monoclonal antibodies. Clin Chim Acta 148: 111-118

11. Matzner Y, Konijn AJ, Shlomai Z, Ben-Bassat M (1985) Differential effect of isolated placental isoferritins on in vitro $\mathrm{T}$ lymphocyte function. Br J Haematol 59: 443-447

12. Sirota L, Kupfer B, Moroz C (1979) Placental isoferritin as a physiological downregulator of cellular immunoreactivity during pregnancy. Clin Exp Immunol 76: 606-611

13. Moroz C, Bessler H, Sirota L, Dulitzky F, Djaldeti M (1987) Difference in the placental ferritin levels measured by specific monclonal antibody enzymoassay in preterm and term delivery. Clin Exp Immunol 69: 702-706

14. Moroz C, Bessler H, Lurie Y, Shakali M (1987) A new monoclonal antibody enzymoassay for the specific measurement of placental ferritin isotype in hematologic malignancies Exp Hematol 15: 258-262

15. Moroz C, Kan M, Chaimoff C, Marcus H, Kupfer B, Cuckle S (1988) Evaluation of the ferritin bearing lymphocytes (FBL) immunodiagnostic test for early detection of breast cancer. Cancer 54: 84-89

16. Moroz C, Marcus H, Zahavi I, Dinari G (1988) Is coeliac disease a pre-malignant state. Lancet II: $903-904$

17. Moroz C, Misrock SL, Siegel FP (1989) Isoferritins in HIV infection: relation to clinical stage $\mathrm{CD} 8$, lymphocytes binding and the pathogenesis of AIDS. AIDS 3: 11-16

18. Gepts W (1981) Changes in islet in diabetes. In: Cooperstein SJ, Watkins D (eds) The islets of Langerhans. Academic Press, New York, pp 321-356

19. Bottazzo GF, Dean BM, McNally JM, Mackay EH (1983) Direct evidence of various immunological phenomena associated with the 'insulitis' process. Diabetologia 25: 142-143 Abstract

20. Boitard C, Dabray-Sachs M, Pouplard A, Assan R, Hamburger J (1981) Lymphocytes from diabetic patients suppress insulin release in vitro. Diabetologia 21: 41-46

21. De Berardinis P, Londei M, James RFL, Lake SP, Wise PH, Feldman M (1988) Do CD 4 - Positive cytotoxic cells damage islet cells in type 1 diabetes. Lancet II: 823-824

22. Pak CY, Eun HM, McArthur RG, Yoon JW (1988) Association of cytomegalovirus infection with autoimmune type 1 diabetes. Lancet II: $1-4$

23. Like AA (1986) Insulin injections prevent diabetes (DB) in biobreeding/worcester (BB/Wor) rats. Diabetes 35: $74 \mathrm{~A}$ (Abstract)

24. Drell DW, Notkins AL (1987) Multiple immunological abnormalities in patients with Type 1 (insulin-dependent) diabetes mellitus. Diabetologia 30: 132-143

25. Shah SC, Malone JI, Simpson RN (1989) A randomized trial of intensive insulin therapy in newly diagnosed insulin-dependent diabetes mellitus. N Engl J Med 320: 550-554

Received: 25 September 1989

and in final revised form: 2 April 1990

Prof. C.Moroz

Rogoff Medical Research Institute

Beilinson Medical Center

Petah Tikva 49100

Israel 